\title{
Comentário sobre Analytical Chemistry
}

ed. R.Kellner, J.-M. Mermet, M. Otto, H.M. Widmer

Wiley-VCH, Weinheim-D-1998

O livro surge associado ao conceito de Eurocurriculum desenvolvido na Divisão de Química Analítica da Federação Europeia de Sociedades de Química (DAC/FECS), como consequência lógica de um aturado trabalho de sondagem efectuado junto de instituições universitárias europeias.

Propondo-se responder à pergunta "o que incluir num curso prégraduado de Química Analítica e a que nível", pretende também dar corpo à interpretação da definição de Química Analítica, que a própria DAC produziu, “A Química Analítica é uma disciplina científica que desenvolve e aplica métodos, instrumentos e estratégias. para obter informação sobre a composição e a natureza da matéria, no espaço e no tempo" [R. Kellner, Education of
Analytical Chemists in Europe, Anal. Chem. 1994, 66. 98 A].

Afirmando-se desempenhar um papel único universitário, está organizado em 16 Capítulos e 7 Anexos em que, ao longo de mais de 900 páginas, 30 autores, reputados Químicos Analistas de mundialmente reconhecida competência científica e pedagógica, apresentam de forma clara, compreensiva e actualizada, com ilustrações q.b., os contributos das respectivas especializações científicas.

É uma óptima referência bibliográfica de que quelquer Químico, Analista e não só, poderá beneficiar, dada a cobertura abrangente, quase enciclópédica, de temas tão diversificados, todos eles essenciais e marcantes do mundo que é a Química Analítica. Daqui se compreende a di- ficuldade na coordenação e harmozição de tão vasto leque de contribuições, particularmente se atendermos a que dois dos editores (R. Kellner e H. Widmer) faleceram na fase final da sua colaboração. Verifica-se algum desequilíbrio, nomeadamente no que toca a quantidade e qualidade de questões e problemas de fim de capítulo. Não se pode também dizer que seja o livro introdutório mais aliciante para um aluno prégraduado, nem que consiga ser explorado na íntegra em todo um curso pré-graduado universitário. Referência importante sem dúvida, ele continuará a sê-la, sobretudo a nível pós-graduado. Aí sentimos que ocupa um lugar dianteiro.

Ao preço de $11950 \$ 00$ é um investimento vantajoso para Químicos Analistas e Bibliotecas de Ciência.

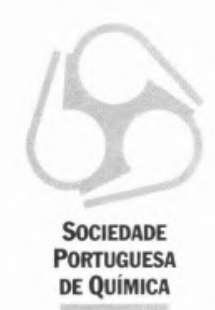

COLABORE
COM A
SOCIEDADE

\section{NÃO ATRASE O \\ PAGAMENTO DAS SUAS QUOTAS}

\section{SPQ - QUOTAS}

$5500 \$ 00$ $3000 \$ 00$ $8500 \$ 00$ 